\title{
Borrowings between the Maya and the Spanish in Yucatán during the 16th century
}

\section{Introduction}

Around 1502, Christopher Columbus on his fourth trip, had the opportunity to discover Yucatan, however he did not, but he was able to communicate with the Mayan people when, by sending his brother Bartholomew to the main land from an island called Guanajas in front to Honduras, he came across a large canoe loaded with diverse merchandise that came from the western parts of New Spain ${ }^{1}$ and with people similar to those of the other islands although with the not so wide forehead ${ }^{2}$ from which he took as a guide "to an old man named Jumbé"3, apparently of greater authority and prudence "that accompanied him to many towns on his way to the east until his language (the Yucatecan Maya surely) was not understood". ${ }^{4}$ This first encounter between Mayans and Spaniards, spontaneous above all, allowed both groups to be astonished at their own possessions and the differences they had physically as well as those of their languages; therefore, the communication between Columbus and Jumbé prevented the group of Spaniards, on that occasion, from knowing something about the great Mayan cities of the region, and the natives of the intentions of the Europeans. After meeting in March 1508 at the famous meeting of Burgos with King Fernando, Vicente Yáñez Pinzón and Juan Díaz de Solís set sail from the port of San Lúcar on June 29 with instructions to discover, before May, lands "a la partenorte facia eloccidente" , which shows that the project of the trip to discover the channel that led to the land of the Specería had been abandoned since October 1507 when the king mentions "me parece que es mejor que eltiempo y elgasto y eltrabajo que se había de poneren lo de la Especieria se pongaenlabrar las minas nuevas y enenviar a la tierra firmedondepostreramente se falloeloro". ${ }^{6}$

With these instructions, Yáñez Pinzón and Díaz de Solís began a defeat that is unknown, but that reached a point in the Guanajas Islands where both arrived with the purpose of "following the land that the Admiral had discovered... and following almost the same I walk... not wanting to confess that the Admiral had been in those parts to claim the discovery... however ... a pilot of his name, Pedro Ledesma, who had gone before with the Admiral told them that he knew those regions. ${ }^{7}$ "From that island they continued their trajectory towards what is today the Gulf of Honduras, there "discovered a great bay... and from there discovered the mountains of Caira"s and other lands later. And for all this it seems that they undoubtedly discovered much of the kingdom of Yucatan ${ }^{9}$ called Camarona according to the map of Ribeiro. The fourth contact was the one that occurred in 1518

${ }^{1}$ Fernando Colón. Historia del almirante don Cristóbal Colón en la cual se da particular y verdadera relación de su vida y de sus hechos, y del descubrimiento de las indias occidentales, llamadas nuevo mundo, second volume, Madrid. 1892 , p. 147.

Ibidem.

${ }^{3}$ The Yucatecan Maya translation would be yum 'sir, father' and be 'way', this is 'the lord of the road' or 'road guide'.

${ }^{4}$ Ibid, p. 149

${ }^{5}$ First paragraph of the royal capitulation of March 23, 1508.

${ }^{6}$ Royal Decree addressed to the Royal officers dated October 21, 1507. Archivo de Indias 148-2-2.

${ }^{7}$ Fernando Colón, Ibidem, p. 145,147.

${ }^{8}$ The mountains of Caira must have been the mountains of Belize.

${ }^{9}$ Bartolomé de las Casas, Historia de las Indias, Chapiter 39, book II.
Volume 6 Issue 2 - 202I

\author{
Raúl Arístides Pérez Aguilar \\ Humanities and languages, University of Quintana Roo, Mexico \\ Correspondence: Raúl Arístides Pérez Aguilar, Humanities and \\ languages, University of Quintana Roo, Mexico, \\ Tel 529831175392, Fax 529838350325, \\ Email rauperez@uqroo.edu.mx
}

Received: July 05, 202I | Published: September 27, 2021

in the expedition of Juan de Grijalva and the first of which a text written by the chaplain of the Navy is preserved, who narrates the events that occurred from the first day of May. This text contains the only description of the time of the discovery of what is now Quintana Roo that has come to us and covers from Cabo Catoche to the Asención Bay; It also contains the first written documentation of the Mayan word taquin: ${ }^{10}$ "el captain les dijo que no queríasinooro que ensulenguallamantaquin" "and from the Cemís voice "idols who worshiped the Taínos' as well as others of Antillean origin: canoa, cacique, maiz, aji not always with the exact definition because it is said that corn is a root with which they make bread. It also speaks of a city as large as Seville that is none other than Zama or çama (now Tulum) and places that are possibly the cove of Xel Ha and the port of Xcaret. ${ }^{1-5}$

The name of Yucatan then reached the ears of Europeans and proof of this is that at the end of 1518 or the beginning of 1519 a letter appeared in Seville that speaks of the arrival of a caravel of "LXXX toneles que viene desta tierra nueva que se dice Hiucata; trae en ella

${ }^{10}$ The word maia and Iuncatam had already been documented around 1505 by Alessandro Zarzi in Venice in the racolta that made the Bartolomé Colón document where there is talk of a ship veniva de una ciertaprovintiachiamata MAIAM vel Iuncatam con molteveste di bambasio de le quale ne eronoforcio di sede di diversicolori. (Harisse:1886:473).

${ }^{11}$ Itinerario de la armada del rey católico a la isla de Yucatán, en la India, el año 1518, en la que fue por Comandante y Capitán General Juan de Grijalva. The italics are mine. 
seis indios desta tierra ... hay capacetes de oro y almireces de oro, é arcos é flechas de oro, é tanta cantidad de oro que decian que son más de veinte é cinco mil pesos de oro de solo estas cosase tantas maravillas que no se puede escribir" 12 Hernán Cortés arrives on the coasts of Yucatan in 1519, where he picks up Jerónimo de Aguilar who would serve as an interpreter but not before using Julian and Melchor to communicate with the Maya. From this time it is the documentation of the voice $k u$ 'God, temple, shrine', and with it they will name all the indigenous pyramids of New Spain. We would consider this the fifth temporary contact, since it will be until the sixth one initiated in 1527 with Francisco de Montejo and Alonso Dávila who begin the conquest of Yucatan in which this encounter will be constant and prolonged because the twenty years it took the Adelantado to pacify the area and The establishment of Spanish institutions was a long and painful process in which the Mayan language felt displaced and along with it, concerning its religion and world view, its origin and its idea of cyclical time. The conquerors, settlers and friars began to learn the language of the Indians in order to achieve greater fruits in the task of economic, religious and cultural control. With the destruction of the codices, books and steles that kept hieroglyphic writings about the stars, history and rulers, the conquerors gave orders to teach the Indians Spanish and keep them from idolatry. It would take many years to get everyone to speak the language brought from Castile, as there are currently thousands of monolingual speakers of Yucatecan Maya.

Being few religious, they had to use some of their Mayan students in their tasks of evangelization and language teaching, and they were appointed as school teachers. These teachers taught Spanish, but many Mayan chiefs and governors refused to learn it influenced by the Ah Kinoob who were responsible for the education of the nobility and opposed the chiefs and principals sending their children to receive Christian education, so In the idolatry trials of 1562 , only a minority of these Mayan chiefs and governors were able to sign the records. These school teachers were auxiliary of chiefs and governors in the reading of letters and in the dictation of offices, and it were also those who transported the ancient Mayan hieroglyphic documents to the Latin letter in order to save the content of the ancient texts from destruction. In addition, they were responsible for the religious teaching of the children of the town. Over time, these school teachers, because of their ability to read and write, came to be considered as the ancient figure of ah kin 'priest', and this was used by several of them to, in complicity with their students, continues with the proper Mayan religious practices and thus won the distrust of the religious. With the visit of Tomás Medel in 1552, the assignment of governors offices to the traditional Mayan authorities began, and between 1560 and 1561 the visitor Jofre de Loaysa authorized the appointment of almost all the batabob' lord caciques' that depended on the former cuúchcabalob $^{13}$ from Tihosuco and Dzindzantun. It is possible that

\footnotetext{
${ }^{12}$ Las nuevas que vinieron de Sevilla de todo lo que traía una carabela que viene de Tierra firme, las cuales enviaron al señor Arzobispo de Granada Presidente del Consejo. This letter was found by Cesáreo Fernández Duro in the Colección Salazar of the Library of the Royal Academy of History and made known in the Boletín de la Academia de la Historia, t. VII, in 1885. I take it from the prologue of José María Asencio to the Colección de documentos inéditos relativos al descubrimiento, conquista y organización de las antiguas posesiones españolas de ultramar. Second series, published by the Royal Academy of History, volume number 11. I Relaciones de Yucatán in 1898.

${ }^{13}$ The cuúchcabal is the family and people that one is in charge of, according to the Calepino Maya de Motul, and always goes before a patronymic when it has this meaning. Do not confuse with the cuúchcabal that precedes a place name because that is what territory means, province governed by a Halach uinic that is to say a political-territorial entity... associated with the exercise of its global political functions (Quezada: 1993: 36). When the Spaniards arrived in Yucatán, there were 18cuúchcabalob from Cozumel to Calkiní.
}

in those years the first charges of scribes of cabildo appeared that displaced the Mayan voice ah dzibhun and that they were in charge not only of ordering the books of the cabildo but of spreading the new legal culture of the written letter that for the Maya facilitated the internal management of the peoples and their insertion in the political system of the Hispanic empire, on the one hand, and the possibility of the Hispanic authority to exercise control over the political, economic and judicial life of the Mayan communities. There was also the case of the use of Yucatecan Maya transcribed into the Latin alphabet as a written communication language that includes borrowings from Spanish as a province for cuúchcabal or governor for batab. ${ }^{14}$ It is convenient to see that in the Mayan archives of Yucatan of the 16th century there are acts of elections, land titles, licenses to have horses or carry shotguns, population censuses, deliberations of the indigenous council, identity cards, etc., and to make a recount of all documents is impossible. Let us therefore circumscribe our search for the borrowings of Maya and Spanish in the texts that we have within our reach, since that is our goal that leaves the dictionaries and vocabularies that were written in the 16th century out of bounds, for obvious reasons about the Yucatecan Maya. ${ }^{15}$

Let our corpus be the texts that were written in the 16th century either by Spaniards, Creoles or Mayans, texts that reveal part of the daily life that took place in the Yucatan peninsula and openly offer the written use of the two languages in contact and borrowings that occur between the two for the reasons imposed by communication between speakers of the same language or another; that is, the narrative strategies may be different and the use of words will also be different if the text written by a Maya, for example, is intended for speakers of that language or if it will be read by strangers. In many texts written in Spanish, the Mayan voices appear as a testimony of a use that expresses the literal equivalence of the voice, the clarification about it only and the relevant information that contains the meaning, but not in the texts translated from Maya to Spanish where its appearance is due to the criteria of the translator or the absence of the equivalent

${ }^{14}$ Others were alliance for the nominal phrase $u$ tabal $u$ can, or treat the people well for mektancah, rule for chichi cah or camcicah (See Okoshi: 2012). In spite of the great roots of the oral and written tradition of their culture, the Mayan scribes adopted witness, testimony, testament, attorney around 1580, and this made the Spaniards require that what the writings by the Mayans adopt the Hispanic style. However, the numbers, official titles, legal material, instruments continued to be written in Maya. Chuchiak (2009) mentions at least 25 Spanish words during petition processes such as civil and religious titles, reverential forms and addresses, forms of humility, social and residential position:

\begin{tabular}{ll}
\hline Maya & Español \\
Halachuinic & Gobernador \\
Ah tepal & Señor, rey \\
TaclalYalanauocyalanakab & Beso las manos de vuestra merced \\
Yub & padre \\
Ah cuchcab & regidor \\
almehenob & noble \\
Ah canancabop & Principal del pueblo \\
Uinicoboay ti cah & Gente de esta villa \\
\hline
\end{tabular}

${ }^{15}$ Those allegedly written by Luis de Villalpando and Gaspar Antonio Chi, although this indigenous possibly intervened in the writing of the Bocabulario hispano-maya de Mayathan, another is Vocabulario muy copioso en lengua española y maya de Yucatán of Fray Alonso de Solana that remains unpublished and the Diccionario maya de Motul de Antonio de Ciudad Real. 
voice in Spanish: chunthanob 'those who have the word' (Lospapeles de losXiu de Yaxá: 57) (here in after Papeles...). In the other case, the Spanish voices that appear in the Mayan texts are due to the fact that there is no significant or significant meaning for that voice in Mayan: colonel ti u yakantunhaoob'colonel de los guerreros', or that having them, the indigenous Amanuense does not he uses it: petiçion and not okotba than, although sometimes in the same text he practices free polymorphism and uses both forms: cayx a names or hunil ca okotba tan petiçion (Papeles...: 123). Be that as it may, borrowings from both sides are common in the texts of the 16th century and will remain so for the following centuries. Our corpus is made up of 1 . La relación de algunas costumbres (1582) de Gaspar Antonio Chi, 2. Historia y crónica de ChacXulub Chen, 3. Itinerario de la armada del rey católico a la isla de Yucatán, en la India, el año 1518, en la que fue por Comandante y Capitán General Juan de Grijalva, 4. Relaciones histórico-geográficas de la gobernación de Yucatán, 5. Los papeles de los Xiu de Yaxá, y 6. Relación de las cosas de Yucatán de fray Diego de Landa. ${ }^{6-10}$

\section{The materials}

La relación de algunas costumbres of Gaspar Antonio Chi. It is a text written around 1582 that is preserved in fragments and contains some customs of the ancient inhabitants of the Yucatan Peninsula, especially residents of the walled city of Mayapán, customs of the pre-Hispanic period that unfortunately have been lost and that the conquest erased. It is noteworthy that there is not a single Mayan voice in the entire text and there are several anti-plainisms that, surely, the Spaniards who arrived from the Caribbean islands took to Yucatan. The author enjoyed the preferences of Fray Diego de Landa and served the Spaniards as an interpreter as well as an indigenous lawyer, professor, lieutenant governor in Maní and business receiver. He also participated in at least 13 of the questionnaires applied to the old Maya or connoisseurs of their customs that in 1577 sent the Spanish crown to the encomenderos of Yucatán as a way to get to know the region. Product of these questionnaires is the historicalgeographical relations that will be discussed later. The text of this descendant of the TutulXiu family, reveals his condition because he came to learn Spanish and Latin and translated sermons into those two languages in Mayan, also because it details the customs of the Mayan indigenous people knew well, and this makes him a historian, although in this task, I emphasize with exaggeration in its text the importance of the TutulXiu family. His status as a polyglot is not felt in the text in which, as has been said, a single Mayan word does not appear, perhaps because the document was ordered by the governor of Yucatán Guillén de las Casas who did not understand the indigenous language. However, he does use cacique and not batab, maiz and not ixim, provincia and not cuúchcabal because his speech is addressed to a Spanish speaker. The milpa and cacao nahuatlisms also appear, but true to its purposes it offers the use of governor and not of batab. The document has historical value because, in a hidden way, the author criticizes the Spanish government for the exploitation they make of the Indians and the high taxes they have to pay and that were lower before the arrival of the men of Castile.

Historia y crónica de Chac Xulub Chen. 1562 Written in May by Nakuk Pech in the second half of the sixteenth century, the work repeatedly shows the positions occupied by the Pech at the time the Spaniards arrived in Yucatan. The reasons for his writing were for the events to become known by the descendants of the author and for them to know that he was originally from the Pech lineage and that for that reason he would not pay any tribute and neither would his children, grandchildren and others. That is to say, the text is directed to the descendants of the Pech lineage in the mother tongue of all in which fidelity is appreciated although with some borrowings of Spanish, but not of the languages of the Antilles and of which the Nahuas spoke. The text contains 51 Spanish borrowings, almost all of them substantive, 2 adjectives: santoocolal 'santafe' and cantolano'plain song' as well as organ, father and cleric building constructions. They are clearly necessary borrowings or that he considered necessary to initiate communication between the Maya to whom Nakuk Pech directs the text. The following table shows the semantic fields of borrowings from Spanish to Maya around 1562.

The Table 1 shows that the largest number of borrowings is in the semantic field of religion followed by that of social organization. This shows two aspects of the life of the Maya where Spanish influence was felt more strongly. The language reflects this process of incorporation into new patterns of life and a new religious ideology although many will continue with pre-Hispanic practices. He mentions three sites unknown to the Maya: Spain, Castile and Mexico and several acquaintances, including Cozumel where Jerónimo de Aguilar was apprehended by his contemporaries. Now, how did Nakuk Pech, the author of this chronicle, learn about this event? La Historia General de las Indias by Francisco López de Gómara published in 1552, surely never reached Yucatan in the 16th century. Therefore, Nakuk Pech could not read it. That is, the scene he narrates: chuci Jeronimo de Aguilar tumenob aCusamil 'Jernónimo de Aguilar ${ }^{16}$ was apprehended by those of Cozumel' could not obtain it from a written source, and this suggests that it was added later; Maybe it was Pío Pérez (17981859) who added it because the text belonged to him along with others of a historical nature since he was a great connoisseur of the Mayan language and history. ${ }^{17}$

In the legal aspect section there are 6 voices in the speech of the Mayan natives, voices that hatch in the text because of the nature of the text and that allude to the lost authority (rod) of the Pech who imparted justice among the governed: yaxma chevarautial justicia ${ }^{18}$ il tumen 'I was the first to grab the rod in favor of justice'. Título and probanza are used by Nakuk Pech to defend their lineage and position because they claim that they are theirs: titulo'my title', inprobanza

${ }^{16}$ Curious fact of this character is the one that Pech presents to us when he assures that lai Aguilar laehantabitunem Naum Ah Pot Cusamiletuyabil 1517 años' this Aguilar who to know had Naum Ah Pot in Cozumel in 1517 years' father-in-law' when It is said in Spanish sources that this man did not have a wife $a h$ because he was a cleric, sources in which the status of son-in-law of Spanish does not appear. What was the source of Nakuk Pech? It is completely unknown.

${ }^{17}$ To broaden the aspects of the possible multiple authorship of the chronicle, as well as others of an identity nature, of self-promotion of the Pech lineage and its alliance with the Spaniards and of a possible reconstruction of the memory of some events with a specific objective, it can be seen the doctoral thesis of Florencia Scandar in which several interesting topics are touched but it is never questioned where the data on the rescue of Jerónimo de Aguilar in Cozumel in 1519 that appear in paragraph 15 of the text come from. Restall (1997: 291) refers to multiple authorship arguing that the words conquest and history are words that do not appear in other Maya text until the eighteenth century, and both are documented in the chronicle. Another proof of a possible multiple authorship is what we have found by observing the presence of the abbreviation of years (as) at the end of paragraph 9: ich habil $1552 \mathrm{a}^{\mathrm{s}} \mathrm{so}$ that it only appears once and the voice años more than 10, the same occurs with the santa voice that appears in paragraph 9 and the abbreviation $\mathrm{s}^{\mathrm{a}}$ in 36 indicating at least two authors.

${ }^{18}$ Justicia has this same meaning in this context, however, pluralized means 'magistrates' as Restall (1997) does in the various texts collected by him from the Carrillo and Ancona Collection Libro de las cuentas y depósitos: ton can batan and $y$ tJusticyas and ytregidores, in the Notarial Archive of the State of Yucatán (year 1775): ton con Batab y Justiasdzay $u$, and in the Títulos de Ebtún: in testamentotutanil in yum Batab y Justicias. 
'my probanza', and bandera when the natives, kneeling, receive the Spaniards in Campeche. In the housing sector only 3 Spanish words incorporated appear: mesa, libro and mesón; although the Maya as a book, paper, the chronicler, for some reason he did not use it. The concepts of table and in did not exist in the indigenous language in the 16th century. Today, in several places of the Yucatan peninsula, caanche' tablado de pallos' (Pérez, svcanche) or 'altar' is used as a synonym for a table, but the chronicler settles table perhaps guided by the context of the word itself: rey ah tepal utziobtimess anachiti España 'and they served the king at the table far away in Spain' where there is no caanche but a mesa. That is, the word España and the previous ah tepal ${ }^{19}$ and rey suggested to the author to use a table and not the patrimonial voice Table 2 .

Table I Semantic fields of borrowings from Spanish to Maya around I562

\begin{tabular}{|c|c|}
\hline Semantic Field & Voices: \\
\hline Social organization: & $\begin{array}{l}\text { Spaniards, Cristianoli, nobles, conxixtadoren, capitanob, advance, king, } \\
\text { encomendero, mayor, oidor, header. }\end{array}$ \\
\hline Legal aspect: & notary, commissioner, title, inprobance, justice, wand, bannersob. \\
\hline Topography: & Mexico, Spain, Castilla. \\
\hline Time: & years, months, August, November \\
\hline Abstracts: & spend 'peace', information, ytoria 'history', conxixta 'conquest', land rise 'war'. \\
\hline Anthroponyms: & $\begin{array}{l}\text { Martín, Fernando, Pablo, Juan, Luis, Antonio, Miguel, Francisco, Alonso, Agustín, } \\
\text { Sebastián, Diego, Rodrigo, Tomás López, Rodríguez Álvarez, Úrsula, Jerónimo de } \\
\text { Aguilar, Fernando Cortés, Espoblaco Lara, Luis de Villalpando, Juan de la Puerta, } \\
\text { Diego de Becal, Juan de Guerrero, Melchor de Benavente, Juan. }\end{array}$ \\
\hline Clothing: & zayo, cape, shoe. \\
\hline Religion: & $\begin{array}{l}\text { baptism, saint, yglesyaob, saint, oleos, cross, parents, order, monastery, missa, } \\
\text { vespers, organ singing, catolanolla plain singing ', bishop, fatherclerigo, oath. }\end{array}$ \\
\hline
\end{tabular}

Table 2 Patrimonial voice

\begin{tabular}{|c|c|}
\hline Semantic field: & Voices: \\
\hline Flora: & $\begin{array}{l}\text { abal 'plum', ak 'bejuco', ah kab 'lord bee', bu'ul bean ', bulsu'uk' type of long grass used for roofing ', boom' white wood stick ', } \\
\text { bek' oak ', bohom' tree whose trunk is hollowed out and produces a sound when hitting 'chaktun' red stone ', chacte' red tree } \\
\text { ', chakah' tree used for fencing ', chaya' certain edible leaf tree ', choch' tree and fruit pear-shaped and milky pulp ', chulul' tree } \\
\text { ', chem' fat tree ', chi' nancen ', chicam' jícama ', chinchinchay' type of chaya ', ek' 'black stick', ek'che 'black tree , ha'as 'banana', } \\
\text { habim 'tree from which carts are made', huhub " certain tree ', is' type of potato, sweet potato ', ixim' corn ', ixhowen' plum } \\
\text { colorada ', ix kanabal' plum yellow ', ik' chile ', kat' species of cucumber ', ki' 'henequén', k'aniste 'tree and yellow fruit outside } \\
\text { and inside', k uche 'type of cedar', kulim 'plum passes', kulul' cactus and its fruit ', k'unche' big fruit tree and thick bark ', k'um' } \\
\text { pumpkin ', k'umche' 'small pumpkin', kup 'type of edible corn', kopo 'poplar', kopte 'siricote', kimin 'true guano, pochote', } \\
\text { kantunhub 'medicinal herb also called rooster's eye', kabalhaw 'certain medicinal root, contrahierba', kitamki 'variety of agave } \\
\text { ', k'umya' medicinal herb ', kanche' type of yellow tree ', k'uik'uk' certain grass to make walls or ceilings ', k'itamak' certain } \\
\text { grass to make walls or ceilings ', kabalhaw' medicinal root ', kantunbub' medicinal herb ', kup bez' certain edible root ', luch' } \\
\text { vessel trees ', makal' type of tuber ', mop' palm, commonly called cocoyol ', makulan' certain herb ', nukabal' greenish plum 'on' } \\
\text { avocado ', op' anona ', ox ', arbol de ramón , pichi'che ', guava tree ', pixoy' tree used in pharmacopeia ', pom' copal ', pich' } \\
\text { guanacaste ', put' papaya ', sabakabal' plum pint ', tuk' cocoyol ', ts'almuy' saramuyo ', ts'alam' timber tree ', ts'in yuca', tuk 'palma } \\
\text { real', won 'pitahaya', xa'an 'type of roofing palm', wayam 'plant of small round edible fruits', ya " zapote ', ya'axnik' white wood } \\
\text { tree ',ya'axche' ceiba ', ya'axbalalche red tree', ya'ax 'green wood tree', yz 'sweet potato', zubinche 'black stick' . }\end{array}$ \\
\hline Fauna: & $\begin{array}{l}\text { ah chab 'anteater', ahch'om 'lord zopilote', ahkabkoh 'kind of lobillo', ahau can 'rattlesnake', ah lu'ub 'catfish', am 'spider', } \\
\text { bobilche 'kind of tiger ', beeh' quail ', cay' fish ', ceh' deer ', chi'ik' pizote ', chiwoh' tarantula ', ch'omak' slut ', chek' mojarra } \\
\text { 'ek'xux' wildcat ', ekbalam 'black jaguar', haleb 'hare', huh 'iguana', ixhunpetskin 'scorpion of the region', k'ek'enil che " pighog } \\
\text { ', koh' felinetype ', kuyum' viper ', ki'ichpachoh 'porcupine', kan 'viper', kutz 'turkey', k'ok'ob 'vibora ponzoñoza', kitam 'pighog', } \\
\text { ku'uk 'squirreltype', mukuy 'turtledove', nom 'partridge', och 'opossum', pa'ay 'zorrillo', zabin 'weasel', sots' 'bat', taximchan } \\
\text { 'jumping viper', tulle 'rabbit', ts'ahcay 'mojarra', ts'itun 'Spider red ', ts'ub' tuza ', ulum' guajolote ', wech' armadillo ', yuc' fawn ', } \\
\text { zamho'ol' colmenero bear'. }\end{array}$ \\
\hline
\end{tabular}

Social organization: $\quad$ ah cuchab 'alderman', batab 'sir', cucheabes 'aldermen', chilam 'interpreter', holpop 'cacique', nacom 'alférez' .

Human body: axil 'warty'

Food: balché 'alcoholic beverage', cochoae 'our bread meal', ça 'atole', sa 'atole'.

Religion ah kin 'priest', chaac 'rain god', chilam iv fortune teller, interpreter ',ku' worshiper, pyramid, God '.

Household goods:

kaan 'hammock, mecate', chem 'canoe', ch'oben 'ingrown earth that smear the body', ch'oy 'bucket to draw water from the well', halal 'arrow', nabte 'spear ', xeme' coral colored beads', ya'ax 'deep green',

Geography:

ts'onoot 'cenote', chak'an 'sabana', che'n 'well', hok 'ciénega', hok'ak'al 'water outlet', sahkab 'white earth', you ex 'place of black ink ', ts'an' sinking '. 
Table Continued...

\begin{tabular}{ll}
\hline Semantic field: & Voices: \\
\hline Dress: & k'ubul 'certain type of touch', kuyub 'women's blouse', ex 'calzón', pati 'narrow blanket', pik 'half-leg petticoat', suyem 'cape', \\
& yubte 'cotton blanket to pay tribute ', kuyub' breastplate to defend against darts'. \\
Language: & Mayat'an 'Mayan language', ah maya 'authentic Mayan language, vile and low-understanding people' \\
Minerals: & tun 'stone' \\
\hline
\end{tabular}

Zayo, cape and shoe are three voices that were integrated into the Mayan lexicon for its constant use. There is in Mayan xanab shoe, espadrille, any kind of foot wear' (Pérez, s.v.xanab) whose reference is different from the foot wear worn by the Spaniards and which was presented to the natives, according to the chronicle, along with the coats and layers. The use of shoes and not xanab is due to the difference between Spanish and indigenous foot wear that the Maya appreciated immediately. About time, only year, November, August and months are recorded. The Maya has haab, skilled or skilled for the year concept, not so for August and November. Year appears several times throughout the chronicle, but almost always accompanied by the Mayan forms and the number: 1541 años' skill in 1541 years' or 1542 años ' chance in 1542 years' or 1542 añoslaihab ca '1542 years was the year in which'. Only rarely does the preposition appear in the structure of the date: t'ubolompisukinil November tiyabil de 1546 años 'to nine days of November of the year of 1546'. Once only the voice also appears months: 4 meses ca uchi 'at four months'.

Of the abstract concepts there is no word in Mayan to designate history, but closely to define information, conquest and peace. For the first one there is numchi 'to give news, to mean' what the chronicler communicates when writing; ilaobyuchultulacalt'ubanalobt'incantahichil immformacion 'saw the events that I tell in my information fulfilled', however, the chronicler prefers Spanish. Paz only appears once: 9 de noviembre, bolulo de passen November 9 peace has arrived ', and the chronicler does not use hunolal 'concordia, paz' for unknown reasons. Katuntah and Katunyah are two Mayan voices that allude to the war and the conquest of lands that the chronicler could use when he settles: altose la tierra 9 de noviembrebol ulo de passen 'raised the earth November 9 returned peace' and the Indians suffered 'Lower the trees, under the branches, under the vines" ${ }^{20}$ but prefers the metaphorized Hispanic form that perhaps for him had a semantic bias that differentiated it from the wars (perhaps the horror left by the firearms) that the Maya had with other tax people and conquered by them, or simply by linguistic fashion. ${ }^{15-22}$

What this part of paragraph 22 of the chronicle narrates is the war like conflict that took place in Valladolid and lasted 4 months between Spaniards and indigenous people in $1546 .{ }^{21}$ The author uses

\footnotetext{
${ }^{19}$ Mayan and Nahuatl hybrid that translates as 'lord, sovereign, majesty'. In Nahuatl, tepeum means to conquer, in tepeualortepual Maya it is 'to reign, to be lord' with a clear political significance. Ah tepal is a term created towards the eleventh century by the conquering momentum of Chchén Itzá converted into U cuchkabal (See chapter 31 of the Crónica de ChacXulub Chen). To broaden the concept, Quezada can be seen: 1993: 25, note 20.

${ }^{20}$ The form yalanche, yalanaban, yalanak appears in the Chilam Balamde Maní, in the Chumayel, in the Matichu Chronicle and is, apparently, a resource of the old Mayan manuscripts because it is presumed to be a well-know formula probably the refrain of one their ancient chants (Brinton: 1882: 126). ${ }^{21}$ The great uprising of Valladolid is recorded by the Chronicle ... From the point of view of the Mayans, this uprising is attributed by Lenkersdorf (2007: 32-33) to the intervention of the sorcery of priests because the chieftains of Sací participated in it, Popolá, Tihosuco, Sotuta, Chancenote, Chetumal and Chauac have been influenced by the Ah kin, as well as the province of Cochua that allied itself to the territories of Sotuta and Cupul to defend themselves from the Spanish invasion of that year (Peralta: 2012: 59)
}

the formula altose la tierra ${ }^{22}$, a form that in the 16th century was very common in the Spanish language to metaphorically refer to the war: "... and what has happened is that during the month of last October on this island a number of Indians were raised and they got together and did a lot of damage "... y lo que ha sucedido es que por elmes de Otubrepasadoenestaisla se alçaron una cantidad de indios é se juntaron é hicieronmuchosdaños...", 23 "alzada la tierra cercaron la ciudad y les dieronmuchaguerracinco u seis meses..."(Del Paso and Troncoso: 1939: 144-145) wrote the treasurer of the port of Dzilam to the king, adding that" this land of war was raised and killed ten or twelve Christians and ten horses "and that the town was abandoned by settlers who moved to Campeche or set off for Peru, although in that same paragraph 22 the Mayan author asserts: canppelucinanil Katun 'four months was the time of war ', and two lines below: ca zihil Katun 'when the war was born' returning to the patrimonial form. The Spanish form is, apparently, a fashion nothing more than, perhaps, few Maya understood when reading or hearing it.

It is fair to note that along with these borrowings that presumably would be known by the Mayan Indians to whom the chronicle was addressed, indigenous graduates or students of the Franciscan schools of Mérida or Mayans who did not know how to read or write, appear several native voices that engage competition with other arrivals in Yucatan from the Antilles, from the high plateau of Mexico or from Spain itself. We can see that the chronicler uses op, imix, ic, $a k$, xamach and dzimin and no anona, maiz, chile, bejuco, comal and horse, the latter (dzimin) 'danta, tapir, beast' that the Maya applied to the horse because he let himself be mounted like some tapirs. All these Spanish borrowings and the others that were incorporated into daily life in Yucatán around 1562 feel like established borrowings that have already entered into written communication with syntactic, use and spelling errors but with clear meanings that refer to a reality in which the cardinal points are written and said in Mayan as well as blood ties, household utensils, social hierarchy and toponymy in general. Competition that can be seen on November 9 buluol spend 4 months ca uchit'ubolonpisukimil November in paragraph 22 of the chronicle. Finally, we see that the preposition of and the conjunction and are recorded twice in the body of the text: Santos óleos and santo that enters into competition with yetel: Maxtunil and yetel ChacXulub Chen 'Maxtunil and ChacXulub Chen', establishes full coexistence: dzaic Patan Yetel Dzicil Tiob and Ca DzaiHanalob 'gave tribute and

${ }^{22}$ Written with $\mathrm{t}$ in imitation of the Castilian interdentally sound.

${ }^{23}$ Text of 1530 collected in Cuba in the Colección de documentos in éditos relativos al descubrimiento, conquista y organización de las antiguas posesiones españolas de ultramar. Second series published by the Royal Academy of History, Volume 4. Island of Cuba, Madrid, Typographical Study Successors of Rivadeneira / Printers of the Royal House, 1888, p. 164. Alvar (1975: 151) comments that raising in America took on the meaning of 'fleeing' and cites this same Cuban example, but I think the text does not refer to the fact that in October the Indians escaped and became greedy, but to who began to war with the Spaniards, that is, they rebelled. Brinton (1882: 230) translates the beginning of paragraph 22: 1546 añoslaihab ca uchiahetzillaealtose la tierra in this way: In the year 1546 there was a conjuration in the highlands of the country with an ignorance of American linguistic fashions 16th century, because he himself accepts that the line is corrupt, and I can only guess at the meaning. 
veneration and food'. It only appears in chapter 23: 9 de noviembre boluol de pasen ... yabil de 1546. Something is clear, $y$ it is used more than yetel and it only appears next to another Spanish borrowing, never between Mayan words as it happens with the conjunction y:ulum y cab yuchahuil hanalo.

Itinerario de la armada del rey católico a la isla de Yucatán, en la India, el año 1518, en la que fue por Comandante y Capitán General Juan de Grijalva. This is a short text written in Spanish that speaks of the defeat of the trip of a group of Spaniards led by Juan de Grijalva who arrives in Cozumel on May 3, 1518, from there it goes to Yucatan that they believe island, to the south they sail to the Ascención bay and return where they had arrived, then go to Lagartos River, arrive at Campeche, then to Tabasco until you reach Veracruz. The image of the land discovered "was wonderful" because "we saw villages and rooms separated from each other, very nicely dressed", all in a clear Spanish with some voices borrowed from the Antilles: cacique, canoa, maiz

\section{Relaciones histórico-geográficas de la gobernación de Yucatán}

Las Relaciones histórico-geográficas de la gobernación de Yucatán (here in after Relaciones...) contain more than 160 Mayan voices recorded by the encomenderos of the various peoples of the Yucate can region who wrote them. The following Table 3 shows the details of these words that structure Las Relaciones... that were requested by the authority and given by "intelligent people of the things of the earth", ${ }^{24}$ that is, some indigenous people who know their history who communicated to the Spanish customs, the flora, fauna, food and other aspects of private and public life, past and present of the Maya.

Table 3 Details of these words that structure las relaciones

\section{Semantic field: Voices:}

governador 1557, don 1557, governadoresob 1557 , lord sf,[I] mayoress sf, lord general lieutenant circa 1640, doña circa 1640, hidalgo circa 1640, regidoresob 16743, kisser sf, captain I646, lord natural sf, ydargo 1717, our king 1688 ,brigader 1738, Ensign 176I, old 1764, sick 1764, died 1764, Field Marshal, I764, Colonel 1779, Mayor 1789, Your Honor 1812, Masseual 1812, Commander 1789, Royal Scribe 1793, ancestors sf.

one thousand seven hundred sixty-four years, August I557, years 1557, week s.f., November 1688, October 1688, March 1722, one thousand seven hundred twenty-two years, one thousand eight hundred seventeen, one thousand eight hundred and twelve years, hulio I76I.

1557, treatment 1608, clerk 1608, probança circa 1640, petition circa 1657, attorney circa 1640 , Original legal defender circa I640, sign circa I640, command I643, aspect: $\quad$ auto sf, sf license, sf reserve, justiçiasob I7I7, book I738, confirmatic 1752, commission 1769, approval sf, protector 1812 , lawyer 1812 .

traça 1557, community 1643, forms 17I7, died I764, list 1812 .

Geography caxtillas.f., probinciails.f., city of Merida 1688

Household items shotgun s.f.
Table Continued..

\begin{tabular}{ll}
\hline Semantic field: & Voices: \\
\hline $\begin{array}{ll}\text { Writing } \\
\text { characters }\end{array}$ & preposition of 1685. \\
Measures & alobal 557. \\
Family: & nephew s.f. \\
\hline
\end{tabular}

The semantic fields that abound in voices are that of flora and fauna because they contain very important aspects in the life of the Mayans that aroused singular attraction in the Spanish encomenderos because, with a better knowledge of them, they could obtain important gains from the indigenous people who had under your orders. Unlike the Mayan text written by Nakuk Pech, the editors or scribes of the 52 Relationship... that are preserved, provide, together with the noun, the details and the characteristics of what is described: "There are also in these provinces a number of cedars that the Indians call cuche[kuché] and another tree called in the same Chulul language, from which the Indians make their weapons: bows and arrows and rodelas; it is very hard black stick like bone "(Merida Relationship), or they make comparisons with Castilian memories:"... they are tigers that the Indians call bobilche [bobilché]; Lions, although not of the ferocity of those of Castile (Relationship of Mama and Kantemó), because the Castilian language is adapting to the new reality, is enriching its lexical inventory, and the notaries, so that the King fully understood what he they were communicating, they had to describe the detail well and / or compare what was described with something that the Castilian king knew or had at hand..$^{22-31}$

There are very few relations... that do not contain Mayan voices, most are populated with them and they complete the Yucatecan reality before the eyes of encomenderos, mayors, Spanish scribes, because the old Mayans understood the instructions they were given before responding to the 50 questions sent by the governor. Las Relaciones ... may not contain Mayan voices, but it is rare that it does not provide any interesting information about the life of the towns before the conquest: "... in time of their kindness they used a wine with which they got drunk, which It was very useful for body health because it is purgative ", and although the Spanish scribe does not document the name of the wine in the Merida Relationship, without doubt the questioned indigenous said balché that he was a known voice throughout the region, because 53 leagues east of Mérida, in the town of Tzamá (today Tulum), the notary noted that "in time of their kindness ... they drank the wine they called quibalche [kibalché] and thus lived healthier than not now" that proves the vitality of the voice that is still used throughout the peninsula by both Spanish speakers of all social classes and Mayan speakers, especially in their religious festivities such as the Hanal Pixan in November.

Of the more than 100 voices that cover these two semantic fields, all of them are still in use in the communities of Maya monolingual speakers and to a lesser extent in other places where contact with Spanish is considerable (Mérida, Cancún, Chetumal, Valladolid, Campeche, Cozumel) but with great vitality in places where Maya continues to be the mother tongue of a large part of the population (Maní, Ticul, Tekax, Mama, Peto, Tizimín, Izamal, Kantunilkín, Tixcacal Guardia, Nuevo Xcan, Chumpón, Tepich, Sacalaca, Sabán, Tihosuco, Calkiní, Hopelchén and several other villages). The voices of the semantic fields, social organization and religion contain only the names of certain important figures of Mayan society and their religious beliefs and faiths. The batab 'cacique', the ah cuchab 'town councilor', the chilam' interpreter', the ah kin 'priest', the kuthat 'ansi call the Indians to their worshiped gods" (Relationship of Valladolid) or 'pyramid, temple 'are voices that were used in ceremonies with

\footnotetext{
24"Instruction and memory" section of Volume I of Relaciones... p. 7.
} 
all due respect for rulers and gods, and that are still used today in ceremonies such as chaacchac rain request ceremony "called okotbatan ${ }^{25}$ by ancient people or in rituals like jetzlu'um 'permission to work or use the land'. There is not much information in Las Relaciones... about these two aspects of the life of the Maya where the 'lawyer' ah kulel, the hmen of the major rituals, the chibal 'caste, offspring', the almathan 'commandment' are lacking Some reason the Mayan informants never said. There is more abundance in the field of household goods ranging from ch'oy'cube' to chulul 'bow' through nabte 'arrow' kaan 'string' and other gadgets among which there is missing a 'house' and caanché 'sticks of sticks 'that do not appear in any of the 52 texts. The geography is reflected only in 6 Mayan voices, among them are: chak'an' vegagrande', hok'ak'al' ciénega, swamp', ch'en 'well', but missing kakaab 'mar', chi pay 'coast' that the indigenous people interviewed by the Spanish encomendero and the scribe never uttered.

The indigenous dress is characterized by being light and fresh: xicol 'cloth vest of the ministers of worship', suyem 'cape', pik'skirt', kuyub 'war chest', kubul's 'certain type of touch' and other garments of man and woman. To refer to their language, the Mayan language, the natives said that they call mayathan [mayat'án] "which means the language of the land which was named for an ancient city that was depopulated as Mayapan" (Relationship of Muxuppipp), but they also call it achmaya ${ }^{27}$ [ahmáya] "which means people of vile and baxo understanding" (Relationship of Popola). The language unit to the Mayans, identifies them as race, as a town because in it they knew of the bacabes'holders of the world', in it they say that they believe in the aluxes'elves of the mountain' and in the wayes 'sorcerers', with her they express themselves to give iswaj' tortilla of tender corn 'and name all the plants, animals, and those that feed and take advantage of its benefits, hence its high number in Las Relaciones... that constitute a large repository of more than 150 Mayan words that they gradually incorporated Yucatecan Spanish as the axil voice applied to the pig's wart skin because axil is 'wart' and that was only documented once and not several as $o p, i k$ or haleb and others that have had since the sixteenth century a continuous presence not only among Mayan speakers but among Spanish speakers of the Yucatecan dialect, and that has reached literary fiction in La flor del henequén by Miguel Caamal, among many other texts, which includes a glossary with more than 60 Mayan voices commonly used throughout the peninsular geography.

\section{Papeles de los Xiu de Xajá}

Three are the parts that constitute these Papeles... A first is the family tree of the Xiu that includes from its founder Hun Uitzil Chac to Don Juan Cimé died at the end of the 17th century. The second is formed by the "Memory of the distribution of the mountains (Maní on August 15, 1557)" with its map that includes more than 50 populations of the Cuúchabalde Maní. The other contains a set of documents that account for the procedures carried out between 1608 and 1817 by the descendants of Don Melchor Xiuin order to respect their honor and preserve their privileges. In this part there is a "Fragment of the history of Yucatan copied by Don Juan Xiu Cimé (May 29, 1685)" that contains many scriptural and discursive characteristics of a Mayan stele. Even Mr. Xiu Cimé says at the end that he copied (the text) of an old paper which is written in characters called anahte. That

\footnotetext{
${ }^{25}$ See Bracamonte (2014: 78).

${ }^{26}$ This voice does not appear in the consulted dictionaries. The Muxuppipp Relationship, which is the only one where it appears, says that it is a touch of cotton torn above the shoulder and below the snuff. Pérez only registers $k u b a$ dress like guaypil 'without further details of the garment.

${ }^{27}$ Bracamonte (2014: 58) speaks of the hachmaya [xachmáya] with the meaning of ancient maya and true maya.
}

is, surely what he copied is a transcript of a stele with Mayan glyphs on a scroll. These Papeles... contain 60 Spanish voices that do not appear in the Chronicle... (1562) because there are 15 others that are part of the repertoire of Nakuk Pech's text that is some years after the Memory of the distribution of the mountains of Maní (1557), the oldest Mayan text in Latin letters that we have been able to obtain. In strict adherence to the temporality of this work, only the Memory... would be our analyzed text, but as the other documents derive from it and its importance and by the registry of Spanish, Antillean and Nahua voices that contain and that seem already incorporated into the Yucatecan dialect, we have considered them part of our corpus. The following chart gives an account of all the Spanish voices that entered the Mayan language and their year of registration. In it we can see the form and in what context they appeared.

The Mayan cuuchabaloob began to suffer a fragmentation process towards the middle of the fifteenth century, the Halachuinic of Maní held weddings with maidens from dominated villages so that their lordship was not affected. The encomenderos respected the Mayan hierarchies so that the Batabes would continue to exercise their authority over the indigenous people and guide them to pay tribute and personal services to reach them. Among the Papeles... there are several transfers of baptismal items in Spanish and tax exemptions also in Spanish. But other documents are in Maya, they are usually requests made for various purposes. The process was as follows: the cacique was writing to the general defender of the natives, sometimes he himself wrote the petition in the Mayan language, then the defender wrote a text in Spanish addressed to the governor where he asked him to order the Yaxá town hall that granted the license or kept the honor and privileges of the applicant, in other words, that gave solution to the matter; The governor then issued the document where the council was ordered to give the requested to the chief, finally the council issued another document in Mayan addressed to the chief in response to his request. ${ }^{28}$ By 1688 , the commandment was ordered to be translated into Maya, a task entrusted to ah tzol than 'general interpreter' to make justice clearer and closer to the people. In these translations from Spanish to Mayan, one from 1688 contains several voices: auto, firma or señoresgobernadores, ciudad de Merida, another from 1722 mentions hidalgosob, one more than 1738 contains brigadier, libroi, probanzas. It is important to clarify that none of the texts written in Maya appear anti-plain or Nahuas voices. They are only documented in the writings in Spanish and there are only 4 anti-plainisms (barbacoa, maiz, cacique, ${ }^{29}$ yuca) and 7 Nahuatlisms (milpa, chile, macehual, petate, mecate, chichigua, cacaguatales).

On the other hand, the use of yetel is abundant in the texts as long as the conjunction and is never used, but the preposition of just in the fourth region of the Memory... and few times more. By 1657 it is the first documentation of the petiçion voice and a few years later, perhaps by 1667 the voice reappears in a Juan Cimé document, but

${ }^{28}$ From 1580 to 1650 the Mayan forms are giving ground to the Hispanic, especially in family process documents such as inheritances of land or property of animals, real estate and continue structured with 9 important points that a request should have: 1. Invocation, 2. Intitulation, 3. Motivation, 4. Device, 5. Petition, 6. Reasons, 7. Place, 8. Salutation and 9. Signature to which was added a cross $(+)$ that was at the top of the text. Of these 10 points, many Mayan texts only carry 4 . With this it can be seen that the Mayan style departed from the Castilian formulas at the time of cultural exchange and also did it in the free form that is used and that is closer of the oral expression that the voice of conscience and momentum meant for the natives.

${ }^{29}$ This voice was started by the listener Tomás López Medel to name both the Halach Uinic and the Batab and soon began to be used among the Indians (1552) but, as noted above, it does not appear in the texts in the Mayan language, but in the Spanish since 1608. 
already in free polymorphism with the Mayan voice okotba than 'supplication, request', and more clearly in another request of 1738 cayxamannes or humble ca okotba than petision 'and I put the letter our request'. Something similar happens in Yetel Can Oh Ahau, nuestrorey King, Ah Tepale, and our great Ahau, our King, AhTepal, ${ }^{30}$ where $c a$ and nuestro share the same semes, the same as rey and ah Tepale, which is recorded from 1557 until 1764, later this year, the treatment changes to señorgobernador and Capitán General. The examples of free polymorphism are several and are documented until 1788 , then petiçion disappears and only the Mayan voice okotba than is used. The legal aspect and social organization contain most of these voices that began to be used by the few Maya who knew how to read and write in Spanish. These scribes did not always understand the terms very well, and although they sometimes did not use them, they were absolutely certain that they were referring to something foreign to their culture and traditions. Hence, when Don Juan Xiu used around 1665 the word calaktereshekcalactereskabaanates "which... in characters called anahte ${ }^{31}$, he thinks not of Latin letters (since he copied the text written on the 'anahte' scrolls that supposedly it contained hieroglyphic writing) but in another form of writing, that is, in a writing with glyphs other than the European one, and therefore it is rare that it does not use the wooh voice 'letter, character'. The word only appears once and is a rare voice in terms of its use for someone who is learning Spanish because it is a concept of the field of writing known only to the Ah kin and other priests of the Mayan ceremonies. ${ }^{32-36}$

The semantic religion field voices are counted, and although calis does not have an exact date of registration, it does cruz but as a limit mark of the lands of several towns in the Cuúchcabal of Maní that appear on the map and in the text, a mark such as the multuntah 'mark limit with lots of land' which is also mentioned in the 22nd section of the Memory... The Mayan text says with reference to the cross context:

\section{Tzulan Umultanil} of stones

\section{0. tidzabicuruzi}

73. çamuyalnadzabicuruzi In Zamuyalna

74. uxul u luumob ah cohob lands of the tecohenses

95. Tixopilch in Uncle DzabiCuruzi was placed a cross

96. lay u xulaniluluumobuticalob ah lands of these

\section{Canulob lae}

97. lay tunhop'anilutzolan up

(lots of stones)

114. Ticalahtzotidzabicuruzi was placed a cross

${ }^{30}$ Tepal is a Mayan and Nahuatl hybrid. In Maya, tepeual or tepual is 'reign'. Tepal is 'king, majesty, manor, highness'. In Nahuatl Tepeua it is 'to conquer' the Mayan tepal ah is 'lord, sovereign', the same as king. The voice was used to create a complex political structure that subordinated the Halach Uinicob of Uxmal and Mayapán (Quezada: 1993: 26 and note 20).

${ }^{31}$ This is only an assumption based on what the text says, however, the Spanish voices that the native uses suggest that Mr. Xiu copied from a source written in Latin letters and not from a parchment with hieroglyphic writing.
115. tidzab ah cananholkaaxi guardians

\section{Diego Yatza}

there

were

put

\section{Juan Balam}

\section{Diego Yatza}

Juan Balam

Where we see that this cross was possibly placed on the pile of stones that constituted a mojonera or land boundary as indicated in lines 69 and 70, the limit of the mountains with the name of their owners appears in lines 74 and 96 , and in 115 the caretakers of the mountain are mentioned that are not the aluxes because they take care of the milpas, but Diego Yatza and Juan Balam of the town of Tekit to the north of Maní that adjoined the Cuúchcabal de Hocabá, one of the 18 cuuchcabalobthat existed when the Spaniards arrived in Yucatán (Quezada: 1993: 39) and that they originated, according to the indigenous tradition, after the destruction of Mayapán in the middle of the XV century.

\section{Relaciones de las cosas de Yucatán}

"In that town I brought together all the main... propose them... to give me skilled and experienced people with whom I could talk and they could give me reason for what I asked them," writes Bernardino de Sahagún about his stay in Tepepulco where he extracted much of the 12 books that make up the general history of things in New Spain. In Yucatan, something similar bequeathed by Diego de Landa in a single book he wrote in Toledo during his stay in 1566 with only the help of his memory that recorded great information about the Maya, their culture, religion, lands, customs, calendar, alphabet, political organization, etc. In a text that barely exceeds 100 pages, this hardworking priest begins by clarifying that Yucatan is not an island or a tip but a mainland. There are more than 100 voices that the religious uses in his narration of facts and description of things and matters. The first thing he names is the land that in the language of Indians he calls uluumilcutzyetelceh 'land of turkeys and deer' also called Petén 'island', the second is the cotochd welling that as a lot to do with the designation of a land tip found by Hernández de Córdoba: Cape Catoche.

The following Table 4 details all the Mayan voices that Diego de Landa used in the construction of his text, voices that he himself defines: zihil that means' to be born ', or translates the phrase: ahau can may that means' the great priest may'. To this picture we must add the names of the days, months, cardinal points and 5 basic colors among others of ceremonies, dances, festivities of demons, place names and patronymics.

Similar to Las Relaciones... which were documented shortly after Diego de Landa's death, the relationship of the things of Yucatan contains abundant information about the flora and fauna of the Yucatecan peninsula. $y a$ 'zapote', ox 'ramón ', kopo' certain tree ', on' avocado 'and taxinchan' snake 'appear in both texts, there are new denominations such as mex' spider fish ', tzimín' danta, tapir 'and by This animal was called the horse, $b a$ is a fish "wide, round and goodeating" fish that, due to its characteristics and shape with which it attacks with the serrated tail and for the use given to that tail, refers to the lebiza or labuzaor libiza that Gómara talks about in the Yucatan customs chapter: "... arch with two quilts of libizasaeta, fish" and in that of the Moctezuma weapons houses: "The stick that these weapons make It is very strong. They toast it, and at the ends they perdenal or bones of the libiza fish, which is festered... "The Lebiza voice is Antillean and refers to a line whose dry skin was used to scratch the game. Today it is widely used in the eastern part of the Yucatan peninsula with the meanings of stripe and sandpaper both in the 
coastal area and inland. They enrich the vocabulary of Spanish these words used by the friar when he explains that the Mayans said ciuthan that he wants to say 'tell him' to the question that the Spaniards asked them about the name of that land, and therefore they called it Yucatan; It also explains what the Ychpa Indians call the city of Mayapán and what it means 'inside the fences' because that city was walled. Maybe it's ichpak, ichilis 'inside' and pak 'is 'masonry wall'. ${ }^{32}$ Landa also explains the phonetic difference between $p a$ 'open' and $p p a$ 'break' and enter tan 'cal' and than' word, speak'. That saying, as a metalinguistic exhibition on the Mayan language and adds that he did not find in that language "six letters of ours that are D, F, G, Q, R and S... but that they have to add others by pressing their lips $[p p a]$ or said stiffness between the tongue and the high teeth"[than]. He doesn't talk about long vowels or glotalized final vowels because his Hispanic ear never distinguished them. However, when he talks about writing he starts drawing the characters of a and puts 3 , these are: short, long and glotalized as in $h a^{\text {' }}$ water', caan'sky and $n a$ ' 'mother 'respectively. He mentions some morphological aspect of the Maya when he says that zihilmeans 'to be born' and caputzihilis 'to be born again'. Baptism is a rebirth for Landa, and this reasoning leads him to talk about how the indigenous language is composed to indicate such rebirth.

Table 4 Details all the Mayan voices that Diego de Landa

\begin{tabular}{ll}
\hline Semantic Field: & Voices: \\
\hline Social organization: & $\begin{array}{l}\text { chaces 'elders of the parties', cayom 'fisherman', } \\
\text { nacom 'alférez', holcanes 'forced, brave'. } \\
\text { Housing: }\end{array}$ \\
& cotoch 'house'. \\
& $\begin{array}{l}\text { mayathan 'mayan language', ciuthan 'say it', } \\
\text { ychpa 'inside the fences' (refers to the city of }\end{array}$ \\
& $\begin{array}{l}\text { Mayapán), hau can may 'great mayan priest', hun } \\
\text { Lanic 'noise of the people', pa 'open' ,ppa 'break', } \\
\text { so 'lime', so 'word, talk'. }\end{array}$
\end{tabular}

It refers to linguistic questions made by the author.

caluac 'vara fat and short', vahonche 'long stick, Appliances: enmesh against demons', kik 'resina', chahalte 'incense', yaxek 'stick', am 'lucky stones', iztahte' tree resin '.

Religion: ah kin sapriest ', chilam' interpreter', bacab' demon 'caputzihil' baptism, rebirth'.

cumchétree ', snowflake' tree ', cihom' tree ', yaxché' ceiba ', chacté red tree', ac 'grass', tixula

Flora: 'flower', tixulaiaxpaliache 'grassto cure sores', ixlaul 'flower', nictétree ', kom 'flor', zam 'treeto cure the bubas', and 'zapote', ox 'ramón', on 'avocado'.

colomché 'game', holcanacot / batelacot 'warrior dance', okotuil 'dance', chan tun yab Entertainment: $\quad$ 'dance', chohom 'dance', naual 'forbidden dance', alcabtan 'dance', kamahau 'dance', xibalbaacot 'demon dance'.

Abstracts: zihil 'born', emku 'descent from God',

Food:

zacah 'ground corn', picula-kakla 'drink made with 4 I 5 grains of roasted corn'.

${ }^{32}$ In Chilam Balam de Chumayel, y chpaa appears as a fortress, but also paa and tulum with the same meaning: 'castle', 'fortress', 'trench' with a certain nuance of difference as tulum is a 'enclosure surrounded by a defensive wall' and Paa is 'castle' (See Brinton: 1882). Barrera Vásquez (2018: 168) says that Ichpá is one of Mayapán's nicknames and means 'between the walls'. What Landa explains is the adjectivation of Mayapán only and perhaps its nickname.
Table Continued..

\begin{tabular}{ll}
\hline Semantic Field: & Voices: \\
\hline & kuch 'butcher bird', uzcay 'corbina fish', alipechol \\
& 'fish', ba 'fish' maybe the libya stripe, mex 'spider \\
fish', taxinchan 'snake', ixyalchanil 'bird', cox & 'bird', maxix 'duck', tzimin 'horse', pay 'skunk', \\
& chic 'badger', zub \\
Dress: & Ixmol 'feather habit', ex 'calzones'. \\
Geography: & dzonot 'cenote, deep water receptacle'. \\
\hline
\end{tabular}

When he speaks of the weather, he does not mention haab 'year' or uinal'month' or kin 'day' for some reason, nor does he documentixim 'corn' or ak 'bejuco', but he does speak the anti-plain voices to which manati, guayabas and others more. The information that Landa provides about the Mayan people is unquestionable although the number of voices in the original language is less than that recorded in Las Relaciones..., but the ones it contains are the most important because few are those that are repeated in both texts, and This makes them complement each other.

\section{Conclusion}

To give name to this new reality that extended without limits before the Spanish eyes, the language of Castile began a slow process of adaptation and adopted words from the Caribbean islands, first, and then spread them on the mainland where it collected more. In this process, the Spaniards learned Antillean, Nahuas, Mayan voices $\ldots$ and stayed with them to designate the reality that involved their lives, and their employment in other latitudes of similar nature or of different degrees of development added the language, made it mestizo .These abundance of voices that became part of the heritage of the new American society are still alive in different regions of the continent: anti-plainism can be heard not only in the Caribbean but in Mexico, Central and South America, the Nahuatlisms have great vitality not only in Mexico but also in Central America, Mayan and Inca voices are used in smaller territories but continue to qualify everyday communication.

The Indians, on the other hand, also modified their language with the cultural transplantation of the Spaniards, acquire voices, modify them, use them to designate aspects of their good vital condition, mix them in the capture of new values of behavior, in the new proposals for social and political organization, and thereby enrich their active and passive vocabulary. Unlike the Spaniards in their texts, these indigenous people did not need to put definitions of governor, notary or petition, or make comparisons because one of the elements was missing in their culture: signature, or if the indigenous voice existed, they used another new indigenous also: corn without comparing it with ixim or they used the heritage without comparing it with the other known indigenous. In the few texts written in Yucatecan Maya these procedures never appear that clarify the meanings of the Spanish or Antillean voices. That is to say, they only wrote 1521 years with its equivalent $1521 \mathrm{ca}$ haab '1521 our year' because the few indigenous people who learned to write ${ }^{33}$ never had the need to send any document to a person outside the American reality and explain the meaning of the voice. They just wrote it down and that was enough. Situation that the Spaniards did who had to legitimize their achievements and discoveries with administrative and chronic travel texts.

\footnotetext{
${ }^{33}$ Cunill (2008) offers an overview of the schools founded in Mérida, Campeche and Maní since 1545 where few men who knew how to write (79) appear in Maní, Hocabá, Sanahcat, Tixcamachel, Tahmek, Sotuta, Kanchunup, Mopilá, Sahcaba, Usil, Tibolón, Calotmul, Peto, Zucab, Nabalon, Tiquibalom. The average is 4 men per town.
} 
The contributions of the indigenous world to Spanish and from this one to that one are not limited only to giving a word, but sometimes a whole cultural content is lent. When the indigenous Bataben Cuchi Ca Inkamah Santo Oleos writes, "when I received the holy oils," it implies that he understands the whole procedure detailed in the baptism ceremony. In the same way, when the Spanish encomendero writes: "There are also some trees called luch that means tree of glasses ... this fruit is split in the middle ... and taken from the inside ... glasses are made that the Spaniards called jícara" indicates that he knows the process of making a jicara because he explains it, which the indigenous does not do because he only mentions ca oci ha t'inpole and ca t'inkamah baptism 'when the water entered my head and when I received the baptism'. The indigenous or Spanish word is used when it is not possible to find a heritage voice that has the same or similar meaning, and if the voice exists, the reference point is the European world, the trees of Castilla, León, Andalucía and more places

The Mayans did not have the same referents as the Spaniards, but some of these embroiled in the meanings of the words of bearded men (the case of year and haab) so important in Mayan culture that it had a calendar with very good gears. The adoption of the words is due to a need for communication between indigenous and Spanish, and this urgency will create a situation of bilingualism when the mestizo population increases and schools are almost always integrated to the convents of the Franciscans in which it was taught to write in Spanish and the Holy Scriptures, activities not always supported by the encomenderos and that led the friars to resort to violence to catechize. When they learned to write the natives, they realized the usefulness of that newly acquired tool that some used to legitimize their indigenous lineage (the case of the Papeles ... and the Crónica...) and to keep their identity firmly rooted through of his writings The friars also learned the Mayan language, many of them like Diego de Landa, Luis de Villalpando, Lorenzo de Bienvenida and Alonso de Solana not only indoctrinated the Indians but also wrote vocabularies and grammar of the indigenous language. And not only did they learn the language, the Creole receiving judge of the town of Tekax Juan de Castañeda y Cabrera asserts that he received the oath of law from Martín Dziu of the town of Yaxá "in his Mayan language that I speak and understand."

We have made a tour in the 16th century through various texts written in Spanish and Mayan to know part of the indigenous and mestizo reality settled in the Yucatan Peninsula and we have traced the various contacts that occurred between the Mayan Indians and the Spanish since the fourth trip of Christopher Columbus (1502) to the presence of Hernán Cortés in the region (1519) and the subsequent settling made by Adelantado Francisco de Montejo of the Spanish institutions and their political and social organization. Of the multiple contacts of which we have spoken, borrowings were produced in the two cultures that were found, the language has registered them as necessary borrowings that, many of them, still haunt both Spanish and Maya in oral situations generally although several have been recorded in various texts. A few years ago I was able to find a credential and vote on the signs issued by the Federal Electoral Institute in Maya, and in several fiction texts in Spanish voices such as chi 'nancen',

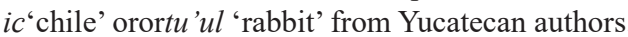

These two Spanish voices were incorporated into the Maya in the twentieth century; the Maya have several centuries in the dialect of the Yucatecan Spanish. Of the Spanish texts studied, only two are the richest: that of Diego de Landa and Las Relaciones... because the number of Mayan voices that contain both exceed two hundred. The Mayan texts, mean while, incorporated Spanish voices into the language of the indigenous people who have remained to date, but others have fallen into disuse as advance, encomendero, scribe, conqueror, gentleman. The borrowings that Spanish introduced in the Mayan language in the 16th century are almost 200 according to our corpus, and could reach that number if the author of the Crónica de Chan Xulub Chen had been less faithful to his mother tongue, but linguistic fidelity he wins, proof of this is that he uses otoch' house' and $n a$ 'house' in the same line: inuotoch Pakilna 'in my house, on the walls of my house' with full awareness of use, the two words are synonyms, but otoch is used when it is said whose house it is: otochcah Mani 'house of the town of Maní' and na does not refer to the owner, but only to the popolna 'house of the people.' The amount, dissemination and vitality of the borrowings that the Spanish has given to the Maya can be found today in any bilingual or monolingual Mayan speaker. They are less in monolinguals but continue to increase in bilinguals, especially in young people with university studies ${ }^{34}$.

The borrowings that the Maya has given to Spanish are numerous. Of the several voices that Barrera Vásquez listed in his 1937 article for the Spanish of Yucatán, in Chetumal 53 they make up the active lexicon of monolingual Spanish speakers (Pérez: 2002), and in Cancun they are 42 (Alcalá: 2009). These disparate amounts do not indicate that the Mayan voices adopted by the Yucatecan dialect have been decreasing. I think it's the other way around. The payroll of Barrera Vásquez must be enriched with birich $<$ bilich 'dog without hair 'referred to the' object or thing of poor quality 'or it comes from bilici' very used thing '(Swadesh et al), kolis' bald ', pirix' buttocks ', tolok' lizard ', jochobear' insistently looking at someone's food ', buth' stuffing ', chichi' grandma ',ch'el' blond ',kabax' without salt ', xek 'revoltura', xoy 'perrilla', lec 'zucchini where tortillas are kept', chuchuluco 'chipote', tilux 'libélula',uix 'urin', tuch 'navel', chechón 'llorón', and many more that are already part of the Yucatecan Spanish because:

1. They have been fully incorporated into the receiving language.

2. They have displaced to some extent the Hispanic synonym.

3. They have morph phonically and syntactically integrated into Spanish using the necessary affixes of plague.

4. They have been accepted by Spanish speakers without realizing their Native American origin.

As we know, each speaker uses his language in a special way, if he has grown up in a monolingual community he will use only voices of that language with the possible borrowings that he has from another or others, if he has done so in a bilingual community or in a Bilingual family, will use both languages in certain situations and before diverse speakers. If this speaker has Maya as his mother tongue and learns

${ }^{34}$ Restall (1997) provides in the several appendices more than 350 Spanish voices that we do not document and that come from various Mayan sources between 1557 and 1838. Although many are outside the chronology of this work, it is important to see their presence not only in notarial documents but in new ones since the voices belong to several semantic fields: yeua 'mare', aia'chair', cuchio 'knife', shirt, matille 'hammer', alaja, carrillo' pulley', tostón, bronso 'bronze 'and other voices of curious creation: baleta, bareta' bullet, papyrus 'desk', siatzimin 'saddle', tzimin brake 'bridle', spoon takin 'spoon', and in this sense encompass broad lines of life daily life of the natives. Even so, the Mayan forms predominate: mehen 'son', kax 'monte', xan'palma ', with its hybrids siacaanché'chair 'bank caanché 'banco'. In the appendices, in the period from 1557 to 1600 there are only 15 Spanish forms that we have not documented. These appendices are enriched with other borrowings from later centuries, indicating that Spanish words in the Mayan language have been growing and changing over the years. Today, words such as emergency, telephone, borrowing, interest and many more are part of the available lexicon of bilingual Maya speakers, especially those based in cities, in small towns the number of voices is low. 
Spanish at 6 or 7 years old, he will grow bilingual with a double lexicon on occasions that will help him name reality and see it through the eyes of the two different cultures. Something like this happened to the Maya of the 16th century in Yucatan and also to the mestizos Pech, Xiu, Uitzil, Cocom, Chan, Dzul and all the native surnames. Those who first acquired Spanish and then Maya were in the same process of naming what their eyes saw. Both languages received, on the other hand, the borrowings that were spoken in the Antilles and in the high lands of Mexico. The presence of these voices arriving in Yucatán from the Caribbean islands and with the Mexicans sitting in Mérida and other places gave the Yucatecan Spanish a special nuance that looks a lot like intonation, but that differs at the lexical level from the Campeche modality and In the Quintana Roo modality, especially in the southern zone that borders Belize in whose districts of Corozal and Orange Walk, a very clear Maya and a Yucatecan Spanish dotted with Caribbean ${ }^{35}$ lexicon can be heard. The Spanish Spaniards is more like Tabasco speaking from Escarcega to Isla del Carmen, but to the Yucatecan from that same point through Champoton, Campeche and the royal road to the north.

It is undeniable that both languages exchanged words when they came into contact in the houses, in the market, in the street, in the churches, in the new Spanish buildings in much of the peninsular geography. The roots of Spanish as a majority language took centuries to occur in Yucatan; the friars, school teachers and the school boys initially educated the children and the noble adults (those who accepted) of the people who continued to speak their mother tongue until their death, and their children as well as the grandchildren they continued the indigenous tradition. This can be seen in the following centuries, since still in $1930,72.2 \%$ of the entire population of the Yucatan state of 5 years and more spoke indigenous language (Bracamonte: 2007: 17). The above gives an idea of the roots of the indigenous language in the Yucatecan population. In Campeche and Quintana Roo the situation is different in the 16th and following centuries. The Mayan Campechens continued to speak their language and to date they continue to do so in the rural sites and small cities that are all those of the state, the jungles of Quintana Roo had very little population in the 16th century, and in the following centuries the situation I do not change. It is until the twentieth century that one can speak of settlement in the eastern region of the peninsula where the Mayan language has never been a majority, today it is spoken in the center of the state (there are towns such as Chumpón or Tixcacal almost monolingual of maya), but in the south and in the north its presence is lower (except in towns such as Kantunilkín, Nuevo Xcan, Solferino, San Ángel and others).

In the sixteenth century, the most populated region of the peninsula was the one that includes the current state of Yucatan. The documents we have analyzed refer to several place names, including Calkiní, Champotón, Campeche as a province and town belong to the state of Campeche, the towns of Bacalar, Kantunilkín, Polé, Polyuc, Sacalaca, Chetumal, Chunhuhub, Tixcacal, Tihosuco, and the province Uyamil are from Quintana Roo, the rest, more than 290 populations, are Yucatecan. In Las Relaciones... they are mentioned because the information comes from 90 villages, none from Campeche, 7 from Quintana Roo and the remaining 83 from Yucatán.

\section{Acknowledgments}

\section{None.}

\footnotetext{
${ }^{35}$ Special mention should be made of the Canarian presence on the peninsula since the 18th century as several voices arriving from the Canary Islands are part of the active lexicon in Campeche, Valladolid, Mérida, Felipe Carrillo Puerto, Tizimín, Chetumal, Bacalar and smaller towns.
}

\section{Conflicts of interest}

The author declares that there is no conflicts of interest.

\section{Funding}

None.

\section{References}

1. Alcalá Phillips. Mayismos en el léxico del español de Cancún, Quintana Roo, México. Tesis de Master of Arts, Brigham Young University, 2009.

2. Alvar Manuel. España y América cara a cara. Valencia, Bello, 1975.

3. Bracamonte Sosa Pedro. "Yucatán: una región socioeconómica en la historia" en Península. UNAM. 2007;II(2):13-32.

4. Bracamonte Sosa Pedro, Ek Elmer. Después de 2012. Libro de la memoria y vaticinios mayas. México, Miguel Ángel Porrúa, 2014.

5. Brinton, Daniel. The maya Crónica. Philadelphia, D.G. Brinton. 1882.

6. Colección de documentos inéditos relativos al descubrimiento, conquista y organización de las antiguas posesiones españolas de ultramar. Madrid, Establecimiento Tipográfico Sucesores de Rivadaneira, Real Academia de la Historia (ed), Segunda Serie, tomo 11. I Relaciones de Yucatán. 1898.

7. Colección de documentos inéditos relativos al descubrimiento, conquista y organización de las antiguas posesiones españolas de ultramar, Madrid, Estudio tipográfico Sucesores de Rivadeneira/Impresores de la Casa Real, 1888, Real Academia de la Historia (ed.), Segunda serie, t. 4. Isla de Cuba.

8. Colón, Fernando Historia del almirante don Cristóbal Colón en la cual se da.

9. particular y verdadera relación de su vida y de sus hechos, y del descubrimiento de las indias occidentales, llamadas nuevo mundo, segundo volumen, Madrid, Imprenta de Tomás Minueza, 1892.

10. Cunill Caroline. "La alfabetización de los mayas yucatecos y sus consecuencias sociales, 1545-1580" en Estudios de cultura maya, vol. XXXI, Centro de Estudios Mayas. UNAM. 2008:163-192.

11. Chuchiak John F. "Maya scribes, colonial literacy and maya petitionary forms in colonial Yucatan" en text and context Yucatec maya literature in a diachronic perspective. Aaceh, Bonner Amerikanistische Studies, 2009.

12. De Ciudad Real Antonio. Calepino Maya de Motul. México, Plaza y Valdés. 2001.

13. De Landa Diego. Relación de las cosas de Yucatán. México, Conaculta. 2003.

14. De las Casas Bartolomé. Historia de las Indias. México, FCE, 1965.

15. De las Casas Bartolomé. Brevísima relación de la destrucción de las Indias. México, Fontamara, 2005.

16. De la Garza Mercedes. Relaciones histórico-geográficas de la gobernación de Yucatán, 2 t, México. UNAM. 2008.

17. Del Paso y Troncoso Francisco. Epistolario de Nueva España 1505-1818. México, Antigua Librería Robredo de José Porrúa e hijos. 1939;III:15331839.

18. De Solana Alonso. Vocabulario muy copioso en lengua española y maya de Yucatán. Mérida, 1580.

19. Díaz Juan. Itinerario de la armada del rey católico a la isla de Yucatán en la India, el año 1518, en la que fue por Comandante y Capitán General Juan de Grijalva, escrito para su alteza por el capellán mayor de dicha Armada [ca. 1522] en Joaquín García Izcazbalceta (ed) Colección de documentos inéditos para la historia de México, México, Imprenta particular del editor, t. I, pp. 281-308.

20. Fernández de Oviedo Gonzalo. Sumario de la natural historia de las Indias. México, FCE. 1996. 
21. Gage Thomas. The English American, his travail by sea an land or, A new survey of the West India's containing a journal of three thousand and three hundred miles within land of America. London, R. Cotes for Humphrey Blanden and Thomas Williams. 1648

22. García Bernal Manuela. Población y encomienda en Yucatán bajo los Austria, Sevilla, Consejo Superior de Investigaciones Científicas. 1978

23. Harisse Henry. Biblioteca Americana Vetustissima. Nueva York. 1886.

24. Lenkersdorf Gudrun. "Tipos de rebeliones en el siglo XVI" en $L a$ resistencia en el mundo maya María del Carmen Valverde (coord.), México. UNAM. 2007:19-45.

25. López de Gómara Francisco Historia general de las Indias. Barcelona Orbis. 1985.

26. Okoshi Harada Tsubasa. "El Cúuchcabal de los Xiu: análisis de su formación y consolidación" en contribution in the new World archeology. Maya political relations and strategies. Krakow, Institute of Archeology, 2012;4.

27. Pech Nakuk. Crónica de ChacXulub Chen en Chrestomathie maya extrait de la library of aboriginal American Littérature de D. Brinton, Paris, Librairie C. Klincksieck, 1894.

28. Peralta Flores Araceli. Los pueblos de la costa oriental de Yucatán en el siglo XVI. Estados Unidos de América, Editorial Académica Española. 2012.
29. Pérez Juan Pío. Diccionario de la lengua maya. Mérida, Imprenta literaria de Juan F. Molina Solís. 1877.

30. Quezada Sergio. Pueblos y caciques yucatecos 1550-1580. México, El Colegio de México. 1993.

31. Quezada Sergio, Okoshi Harada Tsubasa. Papeles de los Xiu de Yaxá. México. UNAM. 2001.

32. Restall Matthew. The maya world. Yucatec cultura and society. 15501850, Stanford, Stanford University Press, 1997.

33. Swadesh Mauricio, et al. Diccionario de elementos del maya yucateco colonial, México. UNAM. 1991.

34. Strecker Matthias, Artieda Jorge. "La relación de algunas costumbres (1582) de Gaspar Antonio Chi”, en Estudios de Historia Novohispana, UNAM, 1978:6

35. Scandar Florencia. Juan Pío Pérez Bermón: vida y obra de un ilustrado yucateco del siglo XIX. Tesis doctoral, Universidad Complutense de Madrid, 2016.

36. Varnhagen, Francisco Adolfo. Vespuce et son premier voyage. Paris, Imprimiere de L Martinet. 1858. 